\title{
Cash Ratio, Debt to Equity Ratio, Return on Asset, Firm Size, Growth dan Dividen Payout Ratio Pada Perusahaan Manufaktur di Indonesia
}

\author{
Lanawati $^{1}$, Amilin ${ }^{2}$ \\ ${ }^{1}$ Universitas Pancasila, Jl. Srengseng Sawah, Jagakarsa, Jakarta Selatan 12640 \\ ${ }^{2}$ Universitas Islam Negeri Syarif Hidayatullah, Jl. Ir. H. Djuanda No. 95, Ciputat, Tangerang Selatan 15412
}

\section{N F O A R T I K E L}

JEL Classification:

G14

G30

Keywords:

dividen cash,

debt to equity,

return on asset, firm size

\section{A B S S T R A C T}

This study aimed to examine the effect of the cash ratio, debt to equity ratio, return on assets and firm size growth of the dividend payout ratio. Samples were tested as many as 118 data for companies that consistently pay dividends for 5 years from 2008 until 2012. The tests were conducted with a multiple regression test. The results show that the return on assets affect the dividend payout ratio. while cash ratio, debt to equity ratio and firm size growth has no effect. Research to be dating should pay attention to the changes associated with the assessment and recognition of the accounts in the financial statements in order to obtain better results .

\section{A B S T R A K}

Penelitian ini bertujuan untuk menguji pengaruh cash ratio, debt to equity ratio, return on asset dan pertumbuhan ukuran perusahaan dari rasio pembayaran dividen. Sampel diuji sebanyak 118 data perusahaan yang konsisten membayar dividen selama 5 tahun dari 2008 sampai 2012. Pengujian dilakukan dengan uji regresi berganda. Hasil penelitian menunjukkan bahwa pengembalian aset mempengaruhi rasio pembayaran dividen. sementara rasio kas, rasio hutang terhadap ekuitas dan pertumbuhan ukuran perusahaan tidak berpengaruh. Penelitian yang akan berkencan harus memperhatikan perubahan yang terkait dengan penilaian dan pengakuan dari akun dalam laporan keuangan untuk memperoleh hasil yang lebih baik.

\section{Pendahuluan}

Dalam aktivitas dipasar modal, para investor memiliki harapan dari investasi yang dilakukannya, yaitu yang berupa capital gain dan dividen. Kebijakan bidang keuangan yang dijalankan perusahaan harus selaras dan serasi dengan tujuan maksimalisasi keuntungan yang merupakan tujuan utama dari perusahaan. Salah satu kebijakan yang utama untuk memaksimalisasi keuntungan perusahaan adalah kegiatan investasi. Semakin besar investasi maka semakin berkurang dividen yang dibagikan, dan apabila dana internal equity kurang mencukupi dari dana yang dibutuhkan untuk investasi maka bisa dipenuhi dari eksternal khususnya dari utang. Dari sisi investor, dividen merupakan salah satu penyebab timbulnya motivasi investor menanamkan dananya di pasar modal. Kebijakan

*Email Korespondensi: 'lana_markus@yahoo.com, ${ }^{2}$ msmagister2@gmail.com 
dividen cenderung menjadi salah satu elemen yang paling stabil dan dapat diprediksi oleh perusahaan, dan sebagian besar perusahaan mulai membayar dividen setelah mereka mencapai tahap kematangan bisnis dan ketika tidak ada lagi kesempatan investasi yang menguntungkan perusahaan Prosentase dari laba yang akan dibayarkan kepada pemegang saham sebagai cash dividend disebut Dividend Payout Ratio.

Umumnya para investor mempunyai tujuan utama untuk meningkatkan kesejahteraannya yaitu dengan mengharapkan return dalam bentuk dividen maupun capital gain. Masalah keagenan (problema agency) juga potensial mengurangi keputusan meningkatkan kesejahteraan pemegang saham sebagai principal. Alasannya, karena pihak manajemen sebagai agen cenderung akan berusaha meningkatkan kesejahteraannya. Pembayaran dividen juga salah satu upaya mengurangi masalah keagenan tersebut. Oleh karena itu, seorang investor atau investor potensial ditentukan untuk mampu memprediksi kebijakan dividen perusahaan. Penelitian tentang faktorfaktor yang mempengaruhi dividen payout ratio telah banyak dilakukan oleh peneliti sebelumnya. Namun penelitian-peneliti ini mempunyai hasil yang berbeda-beda (tidak konsisten). Melihat fenomena adanya research gap dan inkonsistensi hasil penelitian-penelitian terdahulu, maka menjadi menarik untuk diteliti lebih mendalam mengenai faktor-faktor yang mempengaruhi dividend payout ratio dengan menggunakan variabel cash position, debt to equity ratio, return on assets, dan firm size pada perusahaan yang terdaftar di Bursa Efek Indonesia periode 2008 $-2012$.

\section{Telah Teori dan Pengembangan Hipotesis}

\section{Teori Keagenan (Agency Theory)}

Teori keagenan menjelaskan hubungan antaraagen(manajemen perusahaan) dan principal (pemegang saham). Menurut Darmawati, et al. (2005), inti dari hubungan keagenan adalah adanya pemisahan antara kepemilikan (principal/investor) dan pengendalian (agent/ manajer). Kepemilikan diwakili oleh investor yang mendelegasikan kewenangan kepada agen dalam hal ini manajer untuk mengelola kekayaan investor. Investor mempunyai harapan bahwa dengan mendelegasikan wewenang pengelolaan tersebut, mereka akan memperoleh keuntungan dengan bertambahnya kekayaan dan kemakmuran investor.

\section{Teori Pensinyalan (Signalling Theory)}

Manajer berkewajiban memberikan sinyal mengenai kondisi perusahaan kepada pemilik sebagai wujud dari tanggung jawab atas pengelolaan perusahaan. Teori sinyal menjelaskan mengapa perusahaan mempunyai dorongan untuk memberikan informasi laporan keuangan pada pihak eksternal. Pengumuman dividen sebagai alat untuk mengirimkan isyarat yang nyata kepada pasar mengenai hasil kerja perusahaan di masa kini dan masa yang akan datang adalah merupakan cara yang tepat meskipun mahal tetapi sangat berarti.

\section{Konsep dan Kebijakan Dividen}

Kebijakan terhadap pembayaran dividen merupakan keputusan yang sangat penting dalam suatu perusahaan. Kebijakan ini melibatkan dua pihak yang mempunyai kepentingan yang berbeda, yaitu pihak pertama para pemegang saham dan pihak kedua perusahaan itu sendiri. Apabila perusahaan ingin menahan sebagian besar dari pendapatan yang tersedia untuk pembayaran dividen adalah semakin kecil. Persentase dari pendapatan yang akan dibayarkan kepada pemegang saham sebagai cash Dividen disebut Dividen payout ratio. Hal yang penting dan biasanya menjadi pusat perhatian investor maupun para analis keuangan (financial analyst) dalam menganalisis data historis adalah posisi keuntungan kompetitif perusahaan, profit margin dan pertumbuhan laba perusahaan, likuiditas aktiva perusahaan terutama berhubungan dengan kemampuan keuangan perusahaan di dalam memenuhi kewajiban jangka pendeknya, tingkat leverage (penggunaan dana pinjaman) terhadap shareholders equity, dan komposisi dan pertumbuhan operasional penjualan perusahaan (Robert Ang, 1997 dalam Puspita, 2009). Teori 
kebijakan deviden terdiri dari sebagai berikut:

\section{Teori ketidakrelevanan dividen (Dividen irrelevance theory)}

Teori ini menyatakan bahwa kebijakan dividen perusahaan tidak mempunyai pengaruh terhadap nilai perusahaan maupun biaya modalnya. Pendukung utama teori ketidak relevanan dividen ini adalah Merton Miller dan Franco Modigliani (MM). Mereka berpendapat bahwa nilai suatu perusahaan hanya ditentukan oleh kemampuan dasarnya untuk menghasilkan laba dan resiko bisnisnya, artinya nilai suatu perusahaan tergantung semata-mata pada pendapatan yang dihasilkan oleh aktivanya, bukan pada bagaimana pendapatan tersebut dibagi diantara dividen dan laba yang ditahan.

\section{Teori "bird in the hand"}

Myron Gordon dan John Lintner yang dikutip Puspita (2009), berpendapat bahwa sesungguhnya investor jauh lebih menghargai pendapatan yang diharapkan dari dividen daripada pendapatan yang diharapkan dari keuntungan modal karena komponen hasil dividen, resikonya lebih kecil.

\section{Teori Preferensi Pajak (tax preference theory)}

Ada tiga alasan yang berkaitan dengan pajak untuk beranggapan bahwa investor mungkin lebih menyukai pembagian dividen yang rendah daripada yang tinggi, yaitu (1) Keuntungan modal dikenakan dengan pajak dengan tarif maksimum $28 \%$, sedangkan pendapatan dividen dikenakan pajak dengan tarif efektif mencapai $39,6 \%$, oleh karena itu, investor yang kaya (memiliki saham besar dan menerima sebagian besar dividen) mungkin lebih suka perusahaan menahan dan menanamkan kembali laba ke dalam perusahaan.

(2) Pajak atas keuntungan tidak dibayarkan sampai saham terjual, dan (3) terhindar dari pajak keuntungan modal apabila saham yang dimiliki oleh seseorang sampai ia meninggal. Sedangkan Bentuk-bentuk Pembayaran Dividen :

1. Cash Dividen, yaitu pembayaran dividen dalam bentuk tunai.

2. Stock Dividen, yaitu pembayaran dividen dalam bentuk saham dengan proporsi tertentu.

3. Script Dividen (promisory notes), yaitu hutang dividen dalam bentuk script atau pembayaran dividen pada masa yang akan datang.

4. Property Dividen, yaitu pembayaran dividen dalam bentuk kekayaan seperti barang dagangan, real state atau investasi dalam bentuk lain yang dirancang oleh dewan direksi.

Faktor fundamental merupakan faktorfaktor yang mempengaruhi kebijakan dividen yang berhubungan dengan kondisi perusahaan (emiten) yang meliputi kondisi manajemen, organisasi, sumber daya manusia, dan kondisi keuangan perusahaan yang tercermin dalam kinerja keuangan perusahaan. Kinerja keuangan ditunjukkan dalam laporan keuangan perusahaan yang meliputi neraca, laporan laba-rugi, laporan perubahan posisi keuangan (yang dapat disajikan dalam berbagai cara seperti laporan arus kas, catatan atas laporan keuangan).

\section{Konsep Dividen Payout Ratio}

Dividen payout ratio yang ditentukan perusahaan untuk membayar dividen kepada para pemegang saham setiap tahun, dilakukan berdasarkan besar kecilnya laba bersih setelah pajak. Jumlah dividen yang dibayarkan akan mempengaruhi harga saham atau kesejahteraan para pemegang saham. Para investor umumnya menginginkan pembagian dividen yang relatif stabil, karena dengan stabilitas dividen dapat meningkatkan kepercayaan investor terhadap perusahaan sehingga mengurangi ketidakpastian investor dalam menanamkan dananya ke dalam perusahaan.

Dividen payout ratio (DPR) adalah rasio yang mengukur jumlah dividen yang dibayarkan kepada para pemegang saham (Jogiyanto, 2006). DPR tergantung kepada kebijakan masingmasing perusahaan. Dividen payout ratio merupakan hasil perbandingan antara dividen yang dibayarkan dengan laba yang tersedia bagi para pemegang saham biasa (Warsono, 2003). Semakin tinggi Dividen payout ratio akan menguntungkan para investor tetapi dari 
pihak perusahaan akan memperlemah internal finansial karena memperkecil laba ditahan. Tetapi sebaliknya Dividen payout ratio semakin kecil akan merugikan para pemegang saham dan internal finasial perusahaan semakin kuat.

Adapun fokus penelitian ini diarahkan padafaktor-faktoryang diduga paling berpengaruh terhadap rasio pembayaran dividen, antara lain: Cash Ratio, Debt to Equity Ratio, Return on Assets, dan Firm Size Growth.

1. Cash Ratio (CR), Cash ratio merupakan salah satu ukuran dari rasio likuiditas (liquidity ratio) yang merupakan kemampuan perusahaan memenuhi kewajiban jangka pendeknya (current liability) melalui sejumlah kas (dan setara kas, seperti giro atau simpanan lain di bank yang dapat ditarik setiap saat) yang dimiliki perusahaan.

2. Debt to Equity Ratio (DER), Debt to equity ratio mencerminkan kemampuan perusahaan dalam memenuhi seluruh kewajibannya, yang ditunjukkan oleh berapa bagian modal sendiri yang digunakan untuk membayar hutang.

3. Return on Assets (ROA), Rasio ini menunjukkan kemampuan perusahaan untuk menghasilkan keuntungan dari setiap satu rupiah aset yang digunakan. Rasio ini juga memberikan ukuran yang lebih baik atas profitabilitas (rentabilitas) perusahaan karena menunjukkan efektivitas manajemen dalam menggunakan aktiva untuk memperoleh pendapatan (Darsono, 2005).

4. Firm Size Growth (FSG), Ukuran untuk menentukan firm size growth adalah dengan mengurangi firm size $\mathrm{t}$ dikurangi firm size $\mathrm{t}-1$ dibagi firm size t-1 dimana firm size dihitung dari total aktiva (Farinha, 2002). Perusahaan besar dengan akses pasar yang lebih baik seharusnya membayar dividen yang tinggi kepada pemegang sahamnya, sehingga antara ukuran perusahaan dan pembayaran dividen memiliki hubungan yang positif (Cleary dalam Farinha, 2002).

\section{Kerangka Pemikiran Penelitian}

Pengaruh Cash Position, Debt to Equity Ratio, Return on Asset dan Firm Size Growth terhadap Dividen Payout Ratio untuk perusahaan Manufakturyang terdaftar diBursaEfek Indonesia dapat digambarkan seperti pada Gambar 1.

Berdasarkan kajian teori di atas, maka dalam penelitian ini hipotesis yang akan diuji kebenarannya adalah :

$\mathrm{H} 1=$ Cash Ratio (CR) berpengaruh signifikan terhadap Dividen Payout Ratio (DPR) pada perusahaan manufaktur di Bursa Efek Indonesia.

$\mathrm{H} 2=$ Debt to Equity Ratio (DER) berpengaruh signifikan terhadap Dividen Payout Ratio (DPR) pada perusahaan manufaktur di Bursa Efek Indonesia.

Gambar I.

Kerangka Pikir

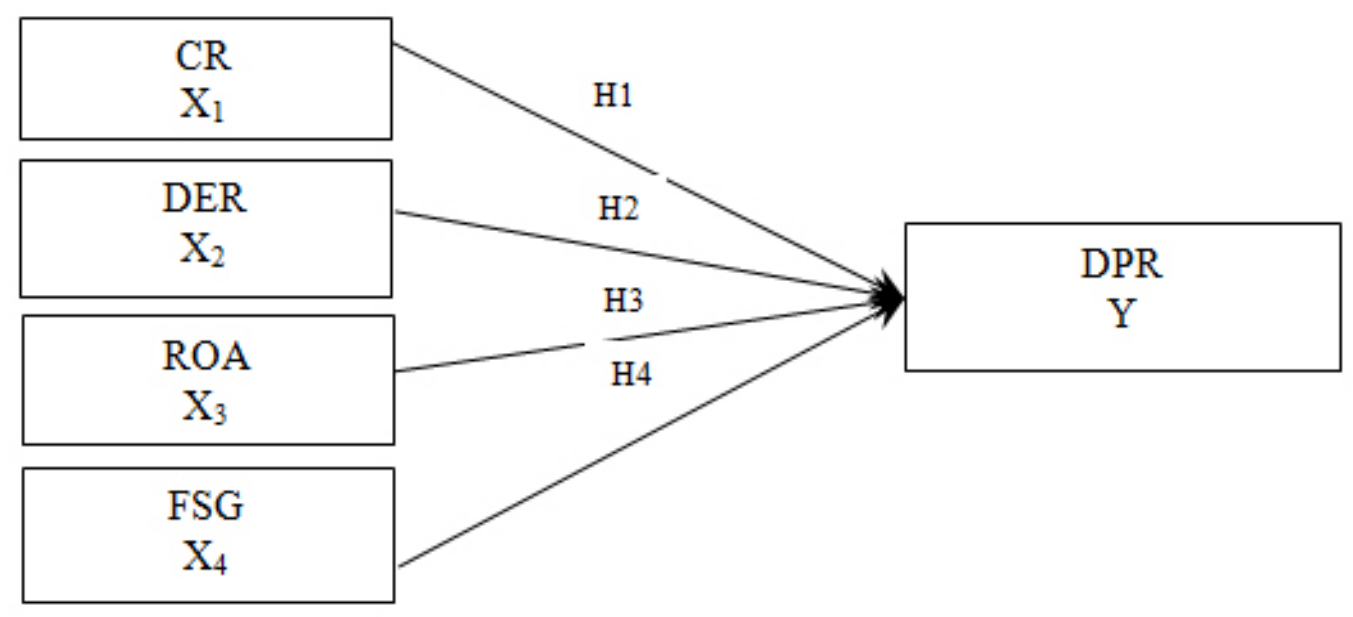


$\mathrm{H} 3=$ Return on Asset (ROA) berpengaruh signifikan terhadap Dividen Payout Ratio (DPR) pada perusahaan manufaktur di Bursa Efek Indonesia.

$\mathrm{H} 4$ = Firm Size Growth (FSG) berpengaruh signifikan terhadap Dividen Payout Ratio (DPR) pada perusahaan manufaktur di Bursa Efek Indonesia.

\section{Metode}

Dalam penelitian ini sampel diambil adalah sebanyak 31 perusahaan selama periode tahun 2008 sampai dengan 2012. Adapun metode pemilihan sampel pada penelitian ini adalah tehnik Purposive Sampling dengan kriteria sampel pada penelitian ini adalah sebagai berikut :

1. Perusahaan manufaktur terdaftar di Bursa Efek Indonesia Tahun 2008 - 2012 dalam yang menerbitkan laporan tahunan (annual report) selama periode pengamatan.

2. Perusahaan menerbitkan laporan keuangan secara konsisten selama periode tahun 2008 sampai dengan tahun 2012.

3. Perusahaan membagikan deviden selama periode penelitian.

Data yang digunakan dalam penelitian ini adalah data Neraca, Laporan Laba Rugi dan dokumen penting lainnya yang bersumber dari informasi keuangan di situs www:idx.co.id dan Indonesian Capital Market Directory (ICMD), data laporan keuangan tahunan (annual report) perusahaan manufaktur yang terdaftar di Bursa Efek Indonesia selama periode Tahun 2008 2012. Untuk pengujian hipotesis, pengolahan data dilakukan dengan cara data Variabel Independen menggunakan data tahun 2008 sampai dengan tahun 2011. Sedangkan data Variabel Dependen menggunakan data tahun 2009 sampai dengan tahun 2012. Hal ini dilakukan dengan pertimbangan bahwa kemampuan membayar Dividen tahun sekarang didasari oleh kinerja tahun sebelumnya.

Variabel penelitian yang dipergunakan dalam penelitian ini terdiri dari empat variabel bebas dan satu variabel terikat. Cash Ratio $\left(\mathrm{X}_{1}\right)$, Debt to Equity Ratio $\left(\mathrm{X}_{2}\right)$, Return on Assets $\left(\mathrm{X}_{3}\right)$,

dan Firm Size Growth $\left(\mathrm{X}_{4}\right)$ merupakan variabel bebas (independent) dan Dividen Payout Ratio (Y) merupakan variabel terikat (dependent).

\section{Cash Ratio $\left(\mathbf{X}_{1}\right)$}

Cash Ratio dihitung berdasarkan perbandingan antara saldo kas akhir dengan hutang lancar (Sudarsi, 2002). Rumus yang digunakan adalah:

Cash Ratio $=$ Saldo Kas

$$
\overline{\text { Hutang lancar }}
$$

\section{Debt to Equity Ratio $\left(\mathrm{X}_{2}\right)$}

Debt to Equity Ratio merupakan rasio hutang terhadap modal. Rumus yang digunakan untuk mengukur rasio ini adalah:

Debt to Equity Ratio = Total Hutang

$$
\text { Total Modal Sendiri }
$$

\section{Return on Assets $\left(\mathrm{X}_{3}\right)$}

Return on Asset dihitung berdasarkan perbandingan laba bersih setelah pajak terhadap total aktiva yang dimiliki perusahaan. Rumus yang digunakan untuk mengukur rasio ini adalah: Return on Asset $=$ Laba Bersih Setelah Pajak

$$
\text { Total Aktiva }
$$

\section{Firm Size Growth $\left(\mathrm{X}_{5}\right)$}

Ukuran perusahaan adalah skala besar kecilnya perusahaan yang ditentukan oleh beberapa hal antara lain total penjualan, total aktiva, dan rata-rata tingkat penjualan perusahaan. Dalam penelitian ini, firm size growth diukur dari prosentase peningkatan atau penurunan dari Total Asset.

\section{Dividen Payout Ratio (Y)}

DividenPayoutRatio adalahperbandingan antara deviden yang dibayarkan dengan laba bersih yang didapatkan dan biasanya disajikan dalam bentuk persentase. Dividen Payout Ratio diukur dengan membandingkan dividen kas per lembar saham terhadap laba yang diperoleh per lembar saham. Rumus yang digunakan untuk mengukur rasio ini adalah :

$$
\begin{aligned}
& \text { Dividen } \\
& \text { Payout Ratio }=
\end{aligned} \quad \begin{aligned}
& \begin{array}{l}
\text { Dividen per lembar saham } \\
\text { (Dividen per share) }
\end{array} \\
& \begin{array}{l}
\text { Laba per lembar saham } \\
\text { (Earninig per share) }
\end{array}
\end{aligned}
$$


Metode analisis yang digunakan adalah regresi berganda, dengan variabel independen terdiri dari Cash Ratio (CR), Debt to Equity Ratio (DER), Return on Assets (ROA), dan Firm Size Growth (FSG). Sedangkan variabel dependen adalah Dividen Payout Ratio (DPR).

Rumus persamaan regresi berganda yang digunakan dalam penelitian ini adalah :

$\mathrm{DPR}=\mathrm{a}+\mathrm{b}_{1} \mathrm{CR}+\mathrm{b}_{2} \mathrm{DER}+\mathrm{b}_{3} \mathrm{ROA}+\mathrm{b}_{4} \mathrm{FSG}+\mathrm{e}$

Teknik analisis yang digunakan dalam penelitian ini terdiri dari dua bagian, yaitu: (1) pengujian asumsi klasik, dan (2) pengujian hipotesis penelitian. Pengujian Asumsi klasik termasuk uji normalitas yang dilakukan untuk mengetahui apakah masing-masing variabel memiliki distribusi normal atau tidak. Cara mendeteksi normalitas adalah dengan pengamatan melalui nilai residual. Normalitas residual model dalam bentuk unstandardize value pada penelitian ini dideteksi dengan menggunakan uji statistik Kolmogorov-Smirnov dengan cara melihat nilai probalitas signifikan yang bernilai diatas nilai 0,05 maka data berdistribusi normal. Selanjutnya uji Autokorelasi dengan cara mendeteksi adanya gejala autokorelasi adalah dengan melihat nilai Durbin-Watson (DW). Asumsi penggunaan analisis DW ini jika digunakan untuk autokorelasi tingkat pertama dan model regresi yang ada intercept (constant) serta tidak terdapat variabel lagi. Kemudian Uji Heteroskedastisitas, untuk mendeteksi ada tidaknya heteroskedastisitas adalah dengan uji Gletsjer dilakukan dengan meregresi independen variable dengan nilai absolute residual model sebagai variable dependen. Hasil yang menunjukkan adanya pengaruh yang tidak signifikan untuk masing-masing independen variable terhadap absolute nilai residual model.

Pengujian model penelitian dilihat dari hasil uji koefisien determinasi. Hasil uji ini digunakan untuk mengetahui seberapa besar kemampuan variabel independen menjelaskan variabel dependen. Koefisien determinasi dapat dilihat pada nilai Adjusted $R$ Square yang menunjukkan seberapa besar proporsi variabel independen yang dapat dijelaskan oleh variabel independen. Semakin tinggi nilai koefisien determinasi dapat menjadi indikator bahwa kemampuan menjelaskannya semakin besar sehingga model diasumsikan baik (fit). Uji Signifikansi t, pengujian ini digunakan untuk membuktikan hipotesis penelitian ( $\mathrm{H} 1, \mathrm{H} 2$, H3, dan H4). Rumusan hipotesis statistik untuk masing-masing adalah sebagai berikut :

H01 : Tidak ada pengaruh Cash Ratio terhadap Dividen Payout Ratio

H11 : Ada pengaruh Cash Ratio terhadap Dividen Payout Ratio

H02 : Tidak ada pengaruh Debt to Equity Ratio terhadap Dividen Payout Ratio

H12 : Ada pengaruh Debt to Equity Ratio terhadap Dividen Payout Ratio

H03 : Tidak ada pengaruh Return on Asset terhadap Dividen Payout Ratio

H13 : Ada pengaruh Return on Asset terhadap Dividen Payout Ratio

H04 : Tidak ada pengaruh Firm Size Growth terhadap Dividen Payout Ratio

H14 : Ada pengaruh Firm Size Growth terhadap Dividen Payout Ratio

Kriteria penolakan hipotesis dengan $\alpha=5 \%$ ditentukan sebagai berikut:

H0 ditolak jika nilai probabilitas

signifikansi $<0.05$

H0 diterima jika nilai probabilitas

signnifikansi $\geq 0.05$

Pengujian model penelitian menggunakan uji $\mathrm{F}$ dan koefisien determinasi. Uji F merupakan pengujian untuk mengetahui pengaruh seluruh variabel independen terhadap variabel dependen secara bersama-sama (simultan). Model dikatakan baik jika paling tidak satu dari variabel yang diuji berpengaruh terhadap dependen variabelnya (Jogiyanto, 2007:142). Pembuktian terkait hal tersebut dapat dilihat dari hasil uji F. Jika nilai $\alpha=5 \%$ maka model dikatakan baik (fit) jika probabilitas hasil signifikansinya $<0,05(5 \%)$. 


\section{Hasil Penelitian dan Pembahasan}

Seleksi sampel dilakukan berdasarkan kriteria sampel, diperoleh 31 perusahaan manufaktur yang memenuhi syarat sebagai sampel. Dengan menggunakan metode data tahun perusahaan (firm years), maka diperoleh data penelitian sebanyak 118 pengamatan, Tabel 1 .

Untuk analisis data diperlukan adanya uji asumsi klasik terhadap model yang telah diformulasikan dengan menguji ada atau tidaknya gejala-gejala multikolinieritas, heteroskedastisitas, autokorelasi dan normalitas. Uji Normalitas dilakukan untuk mengetahui distribusi Normalitas dari Residual Model (Unstandardize Residual) Pengujian dilakukan dengan Uji One Sample Kolmogorov-Smirnov. Berdasarkan hasil uji One Sample Kolmogorov-Smirnov diperoleh hasil 0.128. Model regresi dikatakan terdistribusi normal jika probabilitas signifikasi nilai unstandardize residual $\geq 0.05$. Berdasarkan hasil tersebut dapat disimpulkan bahwa nilai residual model (unstandardize residual) berdistribusi normal.

Berdasarkan hasil perhitungan tampak bahwa dari 31 perusahaan sampel dengan 118 pengamatan, nilai terendah Dividen Payout Ratio (DPR) selama periode 2008 - 2012 sebesar 0,070, nilai tertinggi sebesar 116,100 dan nilai rata-rata DPR sebesar 40,28280 dengan standar deviasi sebesar 25,800353. Nilai Cash Ratio memiliki rentang yang sangat jauh antara terendah 3,831 dan nilai tertinggi 845,203 serta rata-rata Cash Ratio sebesar 140,26193 yang jauh dari nilai tertingginya. Nilai rata-rata total hutang terhadap modal sendiri(debttoequityratio) sebesar 1,18712 yang sangat jauh dari dari nilai terendahnya 0.1 dan nilai tertingginya 17,660 . Nilai laba bersih setelah pajak terhadap total aktiva (ROA) perusahaan sampel memiliki rentang nilai yang sangat jauh antara nilai terendah 0,65 dengan nilai tertingginya 56,920 , serta rata-rata sebesar 15,42860 yang jauh dari nilai tertingginya. Nilai Firm Size Growth perusahaan sampel memiliki nilai terendah sebesar $(5,718)$ dan nilai tertinggi sebesar 50,020, serta nilai rata-rata 5,56145.

Koefisien determinasi $\left(R^{2}\right)$ digunakan untuk mengetahui kemampuan variabel independen (X) dalam menjelaskan variabel dependen $(\mathrm{Y})$. Dari tabel terlihat bahwa nilai $\mathrm{R}$ adalah 0.472 atau 47,2 persen menunjukkan korelasi yang baik karena nilai $\mathrm{R}>5$ persen. Nilai adjusted $R$ Square adalah 0,196 yang berarti variabel Dividen Payout Ratio dapat dijelaskan oleh variabel independen yaitu Cash Ratio, Debt to Equity Ratio, Return On Asset dan Firm Size Growth adalah sebesar 19,6 persen. Sedangkan sisanya 80,4 persen dijelaskan oleh variabel lain yang tidak diteliti dalam penelitian ini.

Uji t dilakukan untuk menguji pengaruh variabel independen Cash Ratio, Debt to Equity Ratio, Return on asset dan Firm Size Growth berpengaruh terhadap variabel dependen

\section{Tabel 1.}

Proses Seleksi Sampel Berdasarkan Kriteria

\begin{tabular}{llcc}
\hline No. & \multicolumn{1}{c}{ Kriteria } & Jumlah & Akumulasi \\
\hline 1. & $\begin{array}{l}\text { Jumlah perusahaan manufaktur yang terdaftar (listing) di } \\
\text { BEI Tahun 2008 - 2012 }\end{array}$ & 134 \\
$\begin{array}{l}\text { Perusahaan yang tidak menerbitkan laporan keuangan } \\
\text { secara lengkap selama periode Tahun 2008 - 2012. }\end{array}$ & $(16)$ & 118 \\
$\begin{array}{l}\text { Perusahaan yang tidak membagikan deviden selama periode } \\
\text { pengamatan secara konsisten. }\end{array}$ & $(87)$ & 31 \\
4. & Jumlah sampel total selama periode pengamatan (5 tahun) & 31 & 155 \\
5 & Penyesuaian observasi t dan t-1 & 31 & 124 \\
6 & Outlier Data & & $(6)$ \\
7 & Data dianalisis (sampel data tahun) & & 118 \\
\hline
\end{tabular}


Dividen Payout Ratio. Hasil pengujian ini digunakan untuk menguji hipotesis 1 sampai dengan 4. Kriteria penolakan hipotesis didasarkan pada nilai probabilitas signifikansi hasil $\mathrm{Uji}$ t. Variabel dikatakan berpengaruh siginifikan apabila nilai signifikan uji $\mathrm{t}$ kurang dari 0,05 (< 5\%) dan dikatakan tidak berpengaruh apabila nilai signifikan uji t lebih atau sama dengan 0,05 $(\geq 5 \%)$. Tabel 2 adalah hasil uji statistik t.

Hasil perhitungan uji $\mathrm{t}$ variabel independen Cash Ratio (CR) memiliki signifikansi sebesar 0,296 > 0,05. Hal ini berarti Cash Ratio (CR) tidak berpengaruh signifikan terhadap Dividen Payout Ratio (DPR). Dengan demikian, hasil uji dari Hipotesis Pertama adalah Cash Ratio berpengaruh tidak signifikan terhadap Dividen Payout Ratio.

Variabel Debt to Equity Ratio (DER) nilai signifikansi 0,105 >0,05. Hal ini berarti Debt to Equity Ratio (DER) tidak berpengaruh signifikan terhadap Dividen Payout Ratio (DPR). Dengan demikian, dari Hipotesis Kedua ditemukan bukti bahwa Debt to Equity Ratio (DER) berpengaruh tidak signifikan terhadap Dividen Payout Ratio. Variabel Return on Assets (ROA) memiliki nilai signifikansi $=0,000<0,05$. Hal ini berarti Return on Asset (ROA) berpengaruh signifikan terhadap Dividen Payout Ratio (DPR). Dengan demikian, penelitian ini menerima Hipotesis Ketiga yang menyatakan Return on Assets berpengaruh signifikan terhadap Dividen Payout Ratio. Variabel Firm Size Growth (FSG) memiliki nilai signifikansi $(p)=0,270>0,05$, berarti Firm Size
Growth tidak berpengaruh signifikan terhadap Dividen Payout Ratio. Dengan demikian, Hipotesis Keempat ditemukan bukti bahwa Firm Size Growth tidak berpengaruh signifikan terhadap Dividen Payout Ratio.

Untuk analisis dan pembahasan antar pengaruh dari masing-masing variabel yaitu sebagai berikut:

1. Pengaruh Cash Ratio terhadap Dividen Payout Ratio

Hasil pengujian menunjukkan bahwa variabel Cash Ratio (CR) tidak berpengaruh signifikan terhadap Dividen Payout Ratio (DPR). Penelitian ini tidak konsisten dengan hasil penelitian sebelumnya yang dilakukan oleh Prihantoro (2003), Risaptoko (2007), Marlina dan Danica (2008), Puspita (2009), dan Ronaldi (2009). Penelitian-penelitian tersebut menyimpulkan bahwa Cash Ratio berpengaruh positif dan signifikan terhadap Dividen Payout Ratio. Berdasarkan hasil pengujian arah pengaruh Cash Ratio menunjukkan arah negatif.

2. Pengaruh Debt to Equity Ratio terhadap Dividen Payout Ratio

Hasil penelitian menunjukkan tingkat resiko perusahaan tidak berpengaruh terhadap kemampuan perusahaan untuk membayarkan dividen. Hasil penelitian ini tidak konsisten dengan hasil yang ditemukan oleh Ismiyanti dan Hanafi (2004) yang menemukan adanya pengaruh resiko terhadap. Hasil penelitian tersebut menyimpulkan bahwa kebijakan hutang

Tabel 2.

Hasil Uji t

\begin{tabular}{|c|c|c|c|c|c|c|}
\hline \multicolumn{2}{|c|}{ Model } & \multicolumn{2}{|c|}{ Unstandardized Coefficients } & \multirow{2}{*}{$\begin{array}{c}\text { Standardized } \\
\text { Coefficients } \\
\text { Beta } \\
\end{array}$} & \multirow[t]{2}{*}{$\mathbf{t}$} & \multirow[t]{2}{*}{ Sig. } \\
\hline & & B & Std. Error & & & \\
\hline \multirow{5}{*}{1} & (Constant) & 31.533 & 4.597 & & 6.859 & .000 \\
\hline & $\mathrm{CR}$ & -.015 & .014 & -.093 & -1.051 & .296 \\
\hline & DER & -1.885 & 1.153 & -.146 & -1.634 & .105 \\
\hline & ROA & .936 & .190 & .413 & 4.921 & .000 \\
\hline & GFS & -.253 & .228 & -.095 & -1.108 & .270 \\
\hline
\end{tabular}


(diproksi dengan leverage) berpengaruh negatif terhadap kebijakan dividen. Hasil temuan ini mendukung hasil penelitian dari Puspita (2009) dimana hasil penelitiannya menunjukkan bahwa Debt to Equity Ratio (DER) tidak memiliki pengaruh yang signifikan terhadap Dividen Payout Ratio(DPR) dan penelitian yang dilakukan oleh Suharli (2006) yang menyatakan bahwa Debt to Equity Ratio (DER) tidak berpengaruh signifikan terhadap Dividen Payout Ratio (DPR). Hasil pengujian dilihat dari arah pengaruhnya menunjukkan arah pengaruh negatif.

3. Pengaruh Return on Asset terhadap Dividen Payout Ratio

Hasil penelitian menunjukkan bahwa Return on Assets (ROA) berpengaruh positif dan signifikan terhadap Dividen Payout Ratio (DPR). Tanda positif dalam penelitian ini sesuai dengan teori Information Contentor Signaling Hypothesis. Hasil ini mendukung hasil penelitian dari Puspita (2009), yang menyatakan bahwa kemampuan perusahaan dalam penggunaaan investasi yang digunakan untuk operasi perusahaan dalam rangka menghasilkan profitabilitas perusahaan akan mempengaruhi perusahaan dalam membagikan dividen. Return On Asset juga merupakan ukuran efektifitas perusahaan dalam menghasilkan keuntungan dengan memanfaatkan aktiva tetap yang digunakan untuk operasi, semakin besar Return On Asset menunjukan kinerja perusahaan yang semakin baik karena tingkat investasi (return) semakin besar.

4. Pengaruh Firm Size Growth terhadap Dividen Payout Ratio

Hasil penelitian menyatakan variabel Firm Size Growth memiliki tanda negatif yang berarti bahwa semakin meningkat firm size Growth akan mengakibatkan penurunan Dividen payout ratio. Hal ini juga berarti bahwa besarnya perusahaan tidak berperan dalam menentukan besarnya rasio pembagian dividen. Hasil penemuan penelitian ini konsisten dengan penelitian Winatha (2001), yang menyimpukan bahwa variabel size of firm berpengaruh negatif terhadap dividen payout ratio. Senada dengan penelitian ini, penelitian Damayanti dan Achyani (2006) juga menyimpulkan bahwa variabel ukuran perusahaan (firm size) tidak berpengaruh signifikan terhadap dividen payout ratio. Namun penelitian ini bertentangan dengan penelitian yang dilakukan oleh Chang dan Rhee dalam Puspita (2009), yang menyatakan bahwa ukuran perusahaan dinyatakan berpengaruh signifikan positif terhadap Dividen payout ratio.

\section{Kesimpulan, Keterbatasan dan Implikasi Hasil Penelitian}

Berdasarkan hasil pengujian ditemukan bahwa model terbuktifit (baik). Pengaruh masingmasing variabel yang dalam hipotesis penelitian dapat disimpulkan hal-hal sebagai berikut:

1. Hasil uji dari Hipotesis Pertama (H1) adalah Cash Ratio berpengaruh tidak signifikan terhadap Dividend Payout Ratio.

2. Dari Hipotesis Kedua (H2) ditemukan bukti bahwa Debt to Equity Ratio (DER) berpengaruh tidak signifikan terhadap Dividend Payout Ratio.

3. Dari Hipotesis Ketiga (H3) dapat dibuktikan bahwa Return on Assets berpengaruh signifikan terhadap Dividend Payout Ratio.

4. Hipotesis Keempat (H4) ditemukan bukti bahwa Firm Size Growth tidak berpengaruh signifikan terhadap Dividend Payout Ratio.

Dalam pengujiannya peneliti mengalami beberapa kendala dimana membuat hasil pengujian yang dilakukan peneliti menemukan hasil sebagai berukut :

1. Berdasarkan hasil Uji Heteroskedastisitas dari empat variabel independen yang diuji, ditemukan tiga variabel diantaranya memenuhi asumsi homogenitas, dan satu variabel yang tidak memenuhi asumsi homogenitas.

2. Berdasarkan Uji Autokorelasi terbukti dari 118 sampel dan jumlah 4 variabel independen ditemukan adanya autokorelasi positif antar variabelnya.

3. Tidak banyak perusahaan di Indonesia yang membayarkan dividen, sehingga sampel data yang dapat dipergunakan terbatas. 
Penelitian ini memberikan saran sebagai berikut:

1. Pembayaran dividen di Indonesia masih belum banyak, terbukti dari jumlah yang membayar dividen hanya sebesar 20\% dari perusahaan manufaktur yang terdaftar di Bursa Efek Indonesia. Sehingga dalam melakukan penelitian dibutuhkan dalam jangka waktu yang panjang untuk mencukupi data sampel yang akan digunakan sebagai penelitian.

2. Untuk menghindari terjadinya autokorelasi pada variabel independen terhadap variabel dependen yang diuji, dalam melakukan penelitian berikutnya sebaiknya mempergunakan data rata-rata bukan data tahun (firm years).

3. Dalam melakukan penelitian berikutnya sebaiknya mempertimbangkan tahun penelitian yang dipergunakan dikarenakan adanya ketentuan pada tahun 2012 perusahaan diwajibkan mengimplementasikan IFRS dalam pembuatan Laporan Keuangan. Beberapa perusahaan sudah menggunakan IFRS dalam penyajian Laporan Keuangan di tahun 2011 yang menyebabkan terjadinya perbedaan penilaian dan pengukuran pada akun-akunnya

\section{Daftar Pustaka}

Damayanti, S dan Achyani, F. 2006. Analisis Pengaruh Investasi, Likuiditas, Profitabilitas, Pertumbuhan Perusahaan, dan Ukuran Perusahaan terhadap Kebijakan Dividen Payout Ratio. Jurnal Akuntansi dan Keuangan Vol.5 No.1 April. p.51-62

Jogiyanto. 2007. Metodologi Penelitian Bisnis, Salah Kaprah dan Pengalaman-Pengalaman. Yogyakarta: BPPE

Marlina, Lisa dan Clara Danica. 2009. Analisis Pengaruh Cash Position, Debt to Equity Ratio, dan Return on Assets Terhadap Dividen Payout Ratio. Jurnal Manajemen Bisnis, Vol. 2, No. 1, Januari 2009, p. 1-6.

Prihantoro 2003. Estimasi Pengaruh Dividen Payout Ratio pada Perusahaan Publik di Indonesia. Jurnal Ekonomi dan Bisnis No.1 Jilid 8. p. 7-14.
Risaptoko, RB,A. 2007. Analisis Pengaruh Cash Ratio, Debt to Total Asset, Asset Growth, Firm size, dan Return on Asset terhadap Dividen Payout Ratio (Studi Komparatif pada Perusahaan yang Listed di BEJ yang Sahamnya Ikut Dimiliki Manajemen dan Yang Sahamnya Tidak Dimiliki Manajemen Periode Tahun 2002-2005. Tesis. Semarang: Universitas Diponegoro.

Sudarsi, Sri. 2002. Analisis Faktor-Faktor yang Mempengaruhi Devidend Payout Ratio pada Industri Perbankan yang Listed Di Bursa Efek Jakarta (BEJ). Jurnal Bisnis dan Ekonomi. Vol.9, No.1, Maret. Hal. 76-88.

Suharli, M. 2006. Studi Empiris Mengenai Pengaruh Profitabilitas, Leverage, dan Harga Saham terhadap Jumlah Dividen Tunai (Studi pada Perusahaan yang Terdaftar di Bursa Efek Jakarta Periode 2002-2003). Jurnal Maksi Vol.6 No.2 Agustus. p.243-256

Syahbana, A. 2007. Faktor-faktor yang Berpengaruh terhadap Kebijakan Deviden pada Perusahaan Manufaktur yang Terdaftar di BEJ Periode 2003-2005. Tesis yang Tidak Dipublikasikan.

Sudarsi, Sri. 2002. Analisis Faktor-Faktor yang Mempengaruhi Devidend Payout Ratio pada Industri Perbankan yang Listed Di Bursa Efek Jakarta (BEJ). Jurnal Bisnis dan Ekonomi. Vol.9, No.1, Maret. Hal. 76-88. 